\title{
Critical turns of aging, narrative and time
}

\author{
By JAN BAARS*
}

\begin{abstract}
As human aging is basically living (in) time, time is a fundamental, but also uncomfortably uprooting concept for aging studies. However, time is usually reduced to chronometric time; a mere measurement that has been emptied of the narratives that were traditionally part of it. Its abstract and instrumental character implies that to become meaningful, chronometric time still depends on narratives. Not only are narratives needed to relate chronometric time to the world, they are also crucial to interrelate the dimensions of lived time: the past, the present and the future. As late modern aging takes place in multiform life worlds and in confrontation with a diversity of social systems, political and cultural macro-narratives play an important role in shaping situations and destinies of aging people. However, because of the prestigious exactness of chronometric time and the role it plays in calculations and statistics, narratives tend to creep in and remain hidden behind chronometric exactness. It is argued that micro-narratives remain important for empirical studies of aging as they articulate human experiences, but that narratives also play an increasingly important role in the interrelation between systemic worlds and life worlds. Therefore, narrative studies should seek more cooperation and critical discussion with disciplines that study macro developments such

* Jan Baars, Interpretative Gerontology, University of Humanistic Studies, Utrecht, The Netherlands
\end{abstract}


International Journal of Ageing and Later Life

as sociology, economics or political science to clarify the role of macronarratives in policies on aging. The article ends with a contemporary example of new systemic (debt) clocks which have a major impact on the lives of many citizens, especially the aged. Although these clocks remain dependent on specific macro-narratives, their ominous ticking tends to hide them and to implode the debate about them.

Keywords: aging and time, systemic narratives, late modern life worlds, interdisciplinary narrative analysis.

\section{Introduction: Aging as Living (in) Time}

It would be convenient, both for me and for the reader, if I could begin this article by giving a clear empirical definition of "time". "Time" cannot, however, be defined in the same way as material objects such as a chair or even mental objects such as a straight line: it is a fundamental concept like "nature" or "life" in the sense that we are always already part of what we try to understand through these concepts. This does not mean that we cannot or should not try to clarify what "time" might be, but we have to be aware that concepts of time are of a complicated nature: we are always already living in time, and in some sense, we are always already living time. And although (unlike stones or trees) we can be aware of this, we cannot step out of time to observe it purely. Getting a clear understanding of time is not just hard because it is always difficult to distance ourselves from what we take for granted: time slips away because we are living (in) it.

This predicament has important implications for the study of aging: it is not possible to study processes of aging as we would study many other processes, because we cannot observe aging in an experimental group and compare the results with a control group that would not age. We can only compare different forms of aging. The notorious Age-Period-Cohort problem (Alwin \& McCammon 2004; Baars 2007; Glenn 2004; Schaie 2007) confronts us with questions about what we have actually established when we have found, for instance, that a high percentage of a group of 70-yearolds suffer from obesity. Is this because of their age? Is it part of their specific cohort identity? Is it because they grew up and older in a specific period in a specific society? Is it a little bit of all that? The epistemological 
riddle of this Age-Period-Cohort problem is another example of the enveloping and elusive nature of time: we are living in time and cannot step out of it to pinpoint it clearly. This fundamental human condition leads to problems even in the most sophisticated research strategies and could be called the Heisenberg principle of uncertainty in aging (Baars 2012): just as it appears to be impossible in quantum theory to determine simultaneously both the position and the momentum of an electron with equal accuracy or certainty, we cannot determine aging, period, or cohort independently from each other. Human aging cannot be studied in a universal or pure form; even a scientifically controlled life in a laboratory would be a life in a specific context that co-constitutes the processes that take place. We can only hope to determine specific forms of aging in retrospect, to learn from such investigations and to aim at developing better futures for human aging.

This does not imply that aging studies should be taken less seriously; it does imply that objectifying approaches are just one way of studying specific aspects of aging, using a specific and limited concept of time. Therefore, the sciences and the humanities have ample reason to work together in aging studies. This also requires a more fruitful interrelation between narrative approaches to aging as living in time and objectifying measurements of ages and durations.

\section{Narrative Foundations of Chronometric Time}

The understanding of time begins with the experience of change: we begin to notice (what becomes subsequently articulated as) "time" or begin to think about it when we experience change. In this process we may discover that some changes are regular and others irregular. Insofar as we try to influence or at least predict processes, we will be primarily interested in discovering regularity. Concepts of chronometric (also called "chronological") time are the products of searching for regular change: its earliest forms were grounded in basic rhythmical movements of the earth and the moon. For ages, even such forms of measuring time have been saturated with meaning; when, for instance, seasons or changing astronomical configurations were seen as inherently meaningful and connected with seasons of life or life stages (Burrow 1986; Sears 1986). 
International Journal of Ageing and Later Life

An important transition in the understanding of time takes place when the concept of time is redefined by early modern philosophers as Descartes and Kant as a mere form of instrumental knowledge. Even though the most advanced quantum-logic clocks still use natural rhythms such as atomic oscillations to measure chronometric durations, these rhythms have been emptied of meaning. Moreover, in constructing chronometric clocks creative interactions with the environment as we see in living nature are avoided as they might change the rhythms and jeopardize the precision that is based on them. The time that is used to measure human aging is not based on the rhythms of living nature, but on the "movements" of dead material such as oscillations of cesium or aluminum atoms (Baars 2012; Yates 2007).

The scientific reduction of time to its measurements has its own practical merits but tends to be seen as the only concept of time that exists or that should be taken seriously. There is, however, also a dependence of chronometric time on other temporal perspectives such as narratives, which becomes obvious when we apply the chronometric perspective to itself. Questions that are inherent in time, even the most simple ones, such as "When did this begin?" or "When does this end?" show their profoundly uprooting character as soon as they are applied to time "itself." For how and when did time begin? We can even ask what might have been before the Big Bang, a question that cannot even be posed within the perspective of chronometric time. Physics as a whole, as we know it, would break down and give up in confrontation with the singular moment of the Big Bang (Penrose 2010).

It is interesting to see how these simple but enigmatic questions were approached by the major pre-modern calendars that are still operating in the late modern world. Their answer, simply put, is that beginning is not a matter of chronometric time but that the idea or metaphor of beginning gives chronometric time its cultural hold and context (Baars forthcoming). Typically, calendars revolve around a major occurrence that opens time in an emphatically new sense that gives chronometric time a zero point from which it can begin to count the years. This occurrence is regarded as so important that it inaugurates a new era. In this way, dating in the Christian calendar starts with the birth of Christ, but in the Muslim calendar it starts with the Hedshra, the flight of Mohammed to Medina. 
The inauguration of time is internally related to narratives about the beginning ("creation") and ending of the world ("the end of times") and is intended to give meaning to the time of the world and the human beings in it, between their beginning (birth) and end (death). Chronometric time needs a calendar or it would not know when to begin in counting the years.

Different calendars can be coordinated in an instrumental way by using chronometric time as the common chronometric units (years, months) make it possible to transpose age-related calculations from one calendar to another. The Christian year 2013 can roughly be transposed into the Jewish year 5773 or the Muslim year 1434, and the ages of people can be counted in much the same way within different calendars. However, this does not mean that calendars only have a chronometric meaning or that the differences between calendars can be eliminated by arithmetic (Baars 1997). In spite of their internal chronometric structure, calendars are not only used to count the years as we do when we speak of calendar age; they show how chronometric time is embedded in cultural narratives. Living within the horizon of such a culturally specific calendar also has consequences for the understanding of aging as living in time. Moreover, the temporal horizons that we find in different cultural interpretations of aging are not static but also changing over time.

\section{Narratives: Meanings behind the Scenes}

These seemingly abstract distinctions have important practical implications because unidentified forms of meaning tend to "slip in" and become fused with instrumental measurements. Although chronometric age (also called "calendar age") is just a measurement of the amount of time that has passed since that person was born, it begets meaningful content from different sources. This may be personal associations between one's age and life events but also broader cultural narratives about people with a certain age. It is not surprising that aging is meaningfully interpreted but it is problematic when the exactness of a chronometric measurement is used to legitimate normative assessments of people with certain ages. It may seem useful to generalize about 60 or 65 years olds for certain policy purposes, but such "aged" persons are very different; not only as unique persons but 
International Journal of Ageing and Later Life

even on major empirical indicators such as income, life expectancy or health. Therefore, retirement policies that generalize according to age can create many new problems, frustrating the societal participation of those who could still give a valuable contribution while continuing to overburden those who are already overburdened. Because the age structures of the life course that were built up in European societies over the last century have come under pressure, there is ample reason to discuss the narratives that play a hidden role in the age-related calculations that are meant to legitimate changes in social policy.

For studies of aging the problem is not that chronometric measurements are not reliable enough or irrelevant; the problem is that precise measurements of somebody's chronometric age are not very informative about that person's aging processes, unless chronometric age is used by societal institutions to organize and structure aging processes. Throughout history and in contemporary contexts we can find so much evidence of differences between persons of the same age that we must conclude that this chronometric dimension is just one, rather overemphasized element in understanding the time that is implicit in processes of aging. All this does not deny processes of aging, senescing or finitude but these issues deserve a broader and deeper temporal understanding (Baars 2010a; 2012).

We can hardly return to static life stages such as "old age" or "being old", but we can also not merely identify aging with getting a higher chronometric age. There may be several so-called "biological clocks" but living nature does not tick according to chronometric time: there is no such clock inside human beings which determines for all time and all places how people age. To clarify the possible interactions of the many processes that result in "aging" in a broad sense, we have to distinguish between three major "discourses": typical clusters of theories, practices, institutions and narratives. The first type are discourses that are based on ages, for instance when people are classified according to their ages or in terms of birth cohorts. The second type consists of discourses about the ways in which biological processes interact with contextual factors, leading to senescing and ensuing health issues. The third are discourses about aging as a social-existential process of persons who continue to lead their lives after they have been labeled by their societies as "aged" or "old" (avoiding the all too extensive meaning of "aging" as a process between birth and death). 
While the first two discourses have been firmly established in late modern societies, in the form of demographics, bureaucratic institutions or laboratories, hospitals and health insurance, the third discourse is far less developed although it could be seen as the most important in guiding the other discourses and the lives of individuals.

In these discursive clusters that surround aging in a broad sense, micronarratives play the important role of articulating and interpreting aging experiences of persons in their life worlds. Such narratives have been the main subject of "narrative gerontology" (e.g. Kenyon et al. 2001). However, micro-narratives are interrelated with macro-narratives in the three domains that were mentioned above: narratives that portray ages and the aged, interpret senescing processes and constitute what agingand by contrast, being young or being "normal" - are supposed to look like (e.g. Gullette 2004). In the remainder of this article I will present some further reflections on such micro- and macro-levels guided by the question how to advance our understanding that aging is basically living (in) time.

\section{The Constitutive Meaning of Narrative}

Throughout history narratives have played a major role in interpreting lives but their constitutive importance for scientific or scholarly research on time has only been acknowledged relatively recently (Baars 2012). After a millennium in which the Aristotelian perspective on time had been dominant, the fifth century theologian and philosopher Augustine of Hippo (354-430) introduced the fundamental role of human consciousness in understanding time, which had been neglected in Aristotle's physics of time. Augustine struggled with the question how to understand time and especially, how to understand time as an experiential reality of mortal beings. Besides Aristotle's ideas, Augustine had to face the classical skeptic conviction which stated that there could be no time because the past is gone, the present does not remain and the future is not yet there. Of course, such a denial of time already presupposes an understanding of time in distinguishing the past, the present and the future. Augustine emphasized, however, in the famous chapter on time in his Confessions (1961) that mortals were confronted with the reality of time and that it would exist in the mind - or in the soul, as he would say - where the past 
International Journal of Ageing and Later Life

exists in its memory, the present in its actual attention and the future in its anticipation.

Twentieth century philosophers such as Husserl (1970), Heidegger (1996) and Wittgenstein (1953) have broken away from the Augustinian emphasis on inner consciousness, which had remained typical for the mainstream of modern philosophy. The liberation of theory from the narrows of rational consciousness, opening up to the constitutive dynamics of existential being, presupposed life worlds or language games brought important changes in the understanding of time (Baars 2012). One of these developments is a deepening awareness of the interrelations between time and narrative (Ricoeur 1984, 1985, 1988). Narratives not only convey what it is to live in the world or in worlds, but also what it means to live in time(s). Here, narratives have again an eminent position: the temporal dimensions of human actions and experiences find their most adequate articulation in narratives. As Ricoeur remarks, there is no "living in time" or "temporal being" without narrative: they are "as closely linked as a 'language-game' in Wittgenstein's terms is to a 'form of life' ... Narrativity is the mode of discourse through which the mode of being which we call temporality or temporal being, is brought to language". (Ricoeur 1991: 91; Wittgenstein 1953). Stories are eminently temporal: even in cultures where "time is money" it will be noticed that they take "precious" time to tell and to listen to; if we take the time to do that we may be reminded that our lives are temporal as well and, indeed, precious in a richer than monetary sense.

In this temporality chronometric time will play a role, but only a modest one. If we would ask somebody what a visit or a long period of work have been like, it would be surprising - and boring - if this person would give us a chronometrically detailed list of "events". Boring, because chronometric measurement does not give a clue about what we should report, because we might measure anything: we would not know what to measure and report. Therefore, just like scientific research requires theories to develop a relevant structure in the face of an immense universe of possible facts or observations, life worlds employ narratives to structure and articulate meaning over time.

As soon as we have a narrative plot, chronometric time (with its emphasis on the timing and succession of events) can be included in the narrative along with other dimensions and experiences. So, narrative time 
does not exclude or oppose chronometric time: what is emphasized and told in the story depends on its meaningful configuration (Ricoeur 1984): chronometric exactness is not important per se, but for reasons following from the plot. The plot transforms a mere succession of incidents into a configuration that can be followed, which has a certain point or theme.

This derived relevance of chronometric time implies that we can check the right date or the duration of events, if that is relevant in the narrative context. In the same way, narratives do not exclude or oppose logical structures. An important logical-temporal question that can be relevant in the narrative context is expressed in the classical logical problem post hoc ergo propter hoc? which poses the question whether something that occurred later was actually caused by the earlier event: whether a temporal sequence can be seen as a causal sequence. In aging studies this fundamental problem re-emerges in the question whether something that happened as people were aging was actually caused by their aging (Baars 2012).

\section{Intertwining the Past, the Present and the Future}

However, the Augustinian interpretation of time as an interrelation of the past, present and future has not lost its fruitfulness and remains highly relevant to understand and open up aging. One of the defining characteristics of aging is that an important part of life has already taken place. Even if the time ahead is regarded as equally exciting or even more so, the past will remain important in shaping the future. Since we have become whoever we are, questions of identity will also concern the past; a past that is, however, never over or completed because the changes that are inherent in aging also change the perception of the past. What is important about our pasts will vary with present situations and future prospects; in this sense, the past is never complete or transparent, but changes as time or life go on.

Here again, chronometric time can be helpful in ordering memories by dating events, but it is only of secondary importance in the intriguing temporal dynamics of memories. Something that happened to me forty years ago can be clear and vivid in my memory, whereas the memory of something which happened a month ago can be almost absent. Moreover, memory as presence of the past does not just comprise what or how we want to remember. We only evoke a part of our memories consciously; another part evokes $u s$ or keeps asking our attention, even when we might 
prefer to forget it. In this context, Hannah Arendt (1958) referred not only to memory as a typically human characteristic of living in time, but also to forgiveness. Interestingly, forgiveness is connected with the promise of opening the future and freeing it from what one has suffered whereas its opposite, resentment, can be a destructive form of what Augustine called the presence of the past in which painful events remain as vivid as if they took place only recently and no time seems to have passed since. Intensified attention for the past can open the future in unexpected ways, when we discover old dreams that could still be fulfilled or restrictions that may have been useful in the past but can be released now. As the German philosopher Hans Georg Gadamer (1993) emphasized: it is not the forced oblivion of the past, but the force with which we examine the past that opens up new opportunities.

But a changing perception of the future - possibly a result of changes in the present - can also lead to new questions about the past and restructure memories. In that way, questions about the meaning of the past also come from questions about the future when there is a need to clarify or to find out something in the past before we can go on. This presupposes an openness to have a future or to be concerned about the future of others, in an intergenerational or a transgenerational perspective (Achenbaum 2007). Nobel Prize Laureate Doris Lessing (2003) recalls in an interview how she had written about an old woman in The Diary of a Good Neighbour. In the novel this woman had the same age as Doris Lessing at the time of the interview: 84 years. The difference between the two characters is that the woman from the novel had decided to be "old", which in her case meant not wanting to have a future. Doris Lessing does not want to be old in that sense. She does not deny that she is getting "increasingly older". Yet the journalist meets a person with a zest for living, who tells her grandchildren: "Live, Live! Don't be scared out of living your life". As she was approaching her 90th birthday she published the novel Alfred and Emily (2009), about the devastating effects of the first World War on the lives of her parents and so, also, on her life. Here again the attention for the past is inspired by a desire to open the future: as Doris Lessing comments: "trying to get out from under that monstrous legacy, trying to get free."

Stories live, however, in the present where they are told or written, listened to or read; they feed on the interest that brings them to life and 
they break off when the interest in them dies. It is from the present only that we reflect on, interpret, amend or criticize stories and wonder if things "really" were like that or whether they should be seen differently. Stories may be reconsidered time and again and possibly retold, for we may continue to ask questions: does this story accurately describe what happened? Should it be interpreted and told this way? Am I doing justice to others and to myself? Do later developments shed another light on what happened?

In spite of well elaborated work on the constitutive importance of narrative (Handel 2000; Holstein \& Gubrium 1997) it remains far from superfluous to emphasize the importance of the present and the future of older persons because in interviews with them and in most narrative work in institutions the attention appears to be one-sidedly directed at the past in variations of the question "What was it like in your days?" or "What has your life been like?" And the retiree may answer: "I have worked all my life" as a banker or a postman or whatever, as if he is not living in time anymore but has arrived at a point of elevated stagnation which allows him to overlook his life as a whole. But for other aging persons it can be quite annoying that it is apparently beyond many people's scope that older persons also live in the present, that these days are also their days, and that they might even be interested in the future. There appears to be a widespread conviction concerning the life course that young people and "normal" adults would be prospectively oriented and make plans for the future, whereas older people are thought to have exclusively retrospective orientations: as if they have lived their lives and should keep themselves occupied with memories. For all of them, young people, so-called normal adults and the old, living in the present tends to fall out between these two preoccupations; a present which is not just a punctual now, but saturated with the past and the future.

\section{Empirical Turns of Temporal Narratives}

Narrative studies appear to be indispensable for empirical research on aging. Whereas molecular biology has its own conceptual strategies to conduct empirical research on senescing cells, empirical research on aging persons which takes their experiences seriously cannot evade to read or to listen to their stories. A strong argument in favor of narrative approaches is 
International Journal of Ageing and Later Life

the obvious importance of narratives for articulating, interpreting and sharing experiences, including experiences of aging.

The ways in which stories are told may have changed from sitting together around a fire to reaching out across cultures by internet, including the use of pictures, movies and audio-visual designs, but the basic activity has not changed although the textual elements have become more complicated. Story-telling appears to be universal among human beings; if there are cultural universals at all, one of them might be precisely this (Brown 1991). Alasdair MacIntyre even exclaims that "Man is in his actions and practice, as well as in his fictions, essentially a story-telling animal" (MacIntyre 1981: 216; Sandel, 1996; cf. Taylor, 1989).

Humans usually have a strong need to communicate important experiences to others, to be able to tell their stories and be heard. Beyond the conventional layer of "How are you?" begins the daily realm of narrative. However, there are also major questions regarding the possible contribution of narrative studies to further our understanding of aging experiences. One concern is, for instance, that writing down narratives or recording them implies a loss of directness. The special quality of narratives as a direct event in the presence of the speaker, is their vividness: a directness and richness of expression in specific situations, where spoken words are accompanied by non-textual forms of expression such as facial expressions, gestures or the unique voice of the speaker. Such loss of directness or vividness in the transition from spoken narrative to written narratives has probably been regretted since the origin of the written word. Already 2500 years ago Plato, who was no friend of literature or the arts in general, recalls in his Phaedrus an already much older Egyptian story about the discovery of the use of letters. The god who had invented writing went proudly to another god because he was sure his discovery would "make the Egyptians wiser and give them better memories". The other god however, answered that what "you have discovered is an aid not to memory, but to reminiscence, and you give your disciples not truth, but only the semblance of truth; they will be hearers of many things and will have learned nothing; they will appear to be omniscient and will generally know nothing; they will be tiresome company, having the show of wisdom without the reality" (Plato Phaedrus 274d-275e). Jean-Paul Sartre and other existentialists went even 
further and opposed the idea that living and telling stories could go together: "This is what fools people: a man is always a teller of tales, he lives surrounded by his stories and the stories of others, he sees everything that happens to him through them; and he tries to live his own life as if he were telling a story. But you have to choose: live or tell" (Sartre 1969: 39).

It is hard to see why such a choice would be necessary; we can live and tell others about our experiences and actions. And to record a narrative or to write it down is also a possible enrichment: the narrative becomes accessible outside the small circle of those who are directly present and opens, invites and facilitates opportunities to interpret the meanings of the text. Narrative brings experience to language, into the world of others. But it remains difficult to understand how this "works" precisely. The relation between experiences of aging and narratives about these experiences is not one of identity or direct representation and, according to the French philosopher Jacques Derrida (1976: 65) there is even an "unheard difference" between the "world" and lived experience.

Both lives and stories contain a surplus of meaning. On the one hand, persons and lives are more than narratives - they are their unfathomable source - and to live is always more than telling stories (Thomae 1998). Moreover, narratives cannot be isolated or individualized in time or social space: references to the present, past and future may change depending on situations and be interrelated in complex ways, as in remembering our plans or forgetting to anticipate. We are also confronted with the remembered pasts and anticipated futures of other people around us: the plans, memories, and actual experiences of children interact and interfere with the plans, memories, and actual experiences that their parents have regarding their own lives and those of their children. We see how these interacting temporal perspectives quickly become very complicated as more people enter the scene and as they change over time (Baars 2012). The many possible meanings of what humans experience and do during their lives can be partially articulated, shared and clarified through narratives but cannot be exhausted by them. And narratives have also lives of their own: they have a certain independence as texts and can, therefore, always be reinterpreted in ways that shed new light on them because their words and metaphors may have more than just one meaning. 
If narratives can claim any empirical status they must be distinguished from systems of linguistic codes or semiotics where every reference to a world outside the text is seen as a referential illusion. Ricoeur's (1984, $1985,1988)$ hermeneutics of narrated time represents an elaborated consideration of the problem how narrative arises from and is prefigured by the world of actions and experiences, but also lives from metaphors, symbols, elements of fiction and other representational dynamics that render it impossible to see the narrative naively as a representation of experiential reality. Some of these delicate processes of co-constituting knowledge have been explored, for instance, for the interview (Fontana \& Frey 2000), for daily life (Ochs \& Capps 2001) and for ethnographic representations (Tedlock 2000).

Here, the problem of the reference of language to a world "outside" language returns in the context of narrative representation: we cannot speak or think about the world without using language, but the (meaningfully shared) world is more than language. Such questions, which energized the later work of Wittgenstein (1953) can be illustrated by the simple (intellectual) experiment in which one would try to live in the word "home", or try to sit on the word "chair": the chair is more than the word chair, although we would constantly need words to describe and understand what sitting on a chair means. Although seemingly abstract, these challenging questions are of great practical relevance. It is an old political trick to try to profit from the lack of direct representation or reference by presenting the improvement of a problematic situation, for instance bad quality of care, by just improving the narrative about it.

Narrative research implies the challenge to reach out from the world of the reader to the world of the narrator, heeding the subtleties of the text without seeing these as the only subject of study. The world of the text may seem clearer to the reader and less problematic than it may actually be because the text emerges from the world of the narrator; which can be very different from the world of the listener or reader so that we must be ready to admit that we don't understand. Moreover, there are also challenges to include other disciplines in the process of understanding the world of the narrator. Studies of aging narratives usually focus on (inter)personal experiences which can easily lead to a microfication (Hagestad \& Dannefer 2001) of aging experiences which fails to acknowledge the ways in which 
societal macro-dynamics co-constitute not only the world of the narrator but also the world of the reader. Moreover, these macro-dynamics are often accompanied by cultural macro-narratives (Baars 2010b) which play an important role in the articulation of policies and their legitimization.

\section{Systemic Macro-Narratives and Life Worlds}

One aspect of the interrelation of micro- and macro-narratives is the question whether all narratives about aging are "equally important"; not in a moral sense, but with respect to the impact they have on policies, public debates or general opinions regarding aging and the aged. The influence of narratives will partly stem from their persuasive content, but most likely the power of the institution or organization they represent will play a major role. Narratives are not only a medium to share or clarify experiences but also to influence audiences: to raise compassion, urge the listener to help or to manipulate the audience. Such tendencies are inherent in narratives but they have become instrumentally sophisticated in systemic worlds to such a degree that they are almost leading a life of their own in creating and playing with audiences.

It is typical of the systemic world that it addresses anonymous people who are only relevant in terms of the specific perspective and interests these systems are after. Even encounters with systemic strategies that can be experienced as depersonalizing or even "inhuman" (Lyotard 1991) are typically embellished with fine narratives, from the usual formula that this will enable them to serve you better, to convincing U.S. citizens that their numerical identity guarantees them social security or its European version that such a personal number grants them citizen service. The bitter irony is that those who are not represented by such numbers are usually worse off.

In late modern society, small and large systems are invading practically all domains of life: the food we buy, the light we switch on, the water we drink, education, work, conflicts with others, income or health care - all of these domains potentially imply a confrontation with systemic worlds. Which specific systems become important to deal with depends on the situation at hand: when persons are out of a job, are having problems with their children or when they are looking for good quality of care for a dementing parent or partner, these situations will confront them with different, usually uncoordinated systems. As far as political systems are 
International Journal of Ageing and Later Life

still rooted in nation states, they are tendentially uprooted by an extremely complex, globalizing economic system with many different dynamics and unpredictable effects which are hardly kept in check by the nation-based political systems, although this is what they still intend or pretend to do.

Moreover, in this rapidly changing globalizing world we can also observe the disintegration of more or less integrated national or regional life worlds where ways of living were taken for granted, into even more diverse life worlds. The presupposition of an integrated life world in Habermas's diagnosis of contemporary society, which roots in his rather abstract and proceduralist understanding of communication, should be left behind for a pluralistic perspective. The concept of pluralistic life worlds that I propose comes closer to what was cited earlier from Wittgenstein's (1953) work, in the sense of a close link between "language-games" and "forms of life". Much depends on whether we are still able to understand experiences of aging as variations of basically shared human experiences of living in time.

One important effect of the intrusion of systemic worlds is that the multiform life worlds may become internally fragmented because of the ways these systems operate as they individualize customers, clients or citizens and take them out of their specific life worlds. This would be a way to reconstruct Habermas's theorem of a "colonization of the life world" (Habermas 1987) which implies that citizens are dominated by the systemic worlds to such a degree that they have internalized the bureaucratic and economic strategies and have lost the ability to communicate and discuss rationally with each other. Hopefully, such a diagnosis is not (yet) adequate. However, even well-developed systems supplying us with goods and services that are needed to live well require countervailing activities from the life worlds. This situation also makes it urgent to introduce and reintroduce narratives of aging experiences from the different life worlds into the public debate to counter the tendency to construct images of aging and the aged according to the interests of specific systems.

Narratives about aging and the aged that are spread by powerful systems, including the media, deserve critical attention because they are much more influential than the narratives that are not backed up by societal power and concentrate less on narrative persuasion. We can observe a cultural ambivalence regarding aging, corresponding with two expanding markets. One market, through commercially designed narratives, 
advertises a successful campaign against the decay of human nature in the form of senescing cells, wrinkles, loss of energy and memory (Hall 2003; Stock 2003). In order to persuade the public to buy commodities, stories of aging people are used and professionally polished to market anti-aging products (King \& Calasanti 2006). In such situations, narratives are intended to keep older people buying and busy, with a primary interest in manipulative strategies. Here, Aging Well is defined paradoxically as Staying Young (Baars 2012).

Another market concentrates on those elderly who are losing the battle to stay young forever, although they may continue to stay alive for a long time. Sometimes it seems as if aging is only seen in terms of the grey waves that will flood the rich countries of the world. These stories set a tone which makes poor music as they depict aging as a thoroughly problematic and upsetting affair; something to be concealed as much as possible under a cloak of youthful activism. But as aging populations put pressure on collective budgets, political narratives about aging are usually dominated by costs of care and pensions, leading to scenarios of aging as a profoundly problematic burden on society: a real threat to their expansion and development (Estes 2006).

\section{The Emergence of New Systemic Clocks}

However, it makes an important difference where political narratives about aging begin as this sets the tone for what follows. The last decennium has seen a series of international crises (wars, housing crisis, credit crunch, banking crisis) with major implications for the public finances of most countries and consequently for those who are dependent on public expenditure for their daily lives. These developments affect the time perspectives in which citizens frame important parameters of their future lives such as income or quality of care. Governments have been eager to confront their citizens with the changing realities of public finances and the need to restrict public budgets because "our common burden" of the national debt grows every hour with huge amounts. This pressing and alarming public situation has been represented by several debt clocks which tend to absorb and neutralize public debate and narratives about public priorities. The main result appears to be a restructuring of public expenditures, targeting those domains of social policy that have already 
International Journal of Ageing and Later Life

been carrying the burden of the financial disasters without having caused them. The ominously ticking US Debt Clock (http://www.usdebtclock. org) adds every 40 seconds 1 million US Dollars to the National Debt and we can wonder whether this clock and similar debt clocks in other countries are not more important for the fate and well-being of aging people than the chronometric clock which determines their ages. In some ways this is, indeed, as the website claims: the "Real Time".

These seemingly neutral, just precisely measuring clocks that set the agenda for the restructuring of public expenditures tend to occlude the processes which have caused these financial crises as they indicate that there is "no time to lose". Especially vulnerable groups in society which did not cause these major crises will be targeted because the expenditures which are meant to keep them out of misery can be reduced relatively easy whereas controlling the financial systems appears to be beyond reach. Another Debt Clock, figuring on the official US Government website of the costs of war since 2001 adds an interesting comment. In language that we know from commercial sponsoring we are informed that this billion-dollar Wasteland is brought to you by the National Priorities Project, "a research organization that analyses and clarifies federal data so that people can understand and influence how their tax dollars are spent". We can wonder whether such understanding or influence are actually made possible by the presentation of these data, but there is at least some notion that these clocks are the results of human activity and not mere parameters of developments that cannot be influenced. In spite of the seemingly selfevidence of these pressing Debt Clocks, there remain good reasons to ask where the narrative about the costs of aging populations begins. Even if we begin this narrative with the need to curb the growing world population which implies aging populations - we would get another tone in these debates. Like the pre-modern calendars, even this apparently very advanced clock needs a narrative to back it up.

\section{Narrative Confrontations - Sustaining Intermediary Tensions}

Although the analysis of the mutual relations between the systemic worlds and the life worlds in terms of power can be clarifying, the different constellations of life worlds and systems should not collapse into a generalizing dichotomy where systems stand on one side and life worlds on 
the other. We need more attention for the intermediate level, between the systemic worlds and the life worlds; a level that is too often neglected as research tends to focus either on the structural and systemic side or on the personal and interpersonal side. In this respect the disciplinary organization of the social sciences and the humanities usually reproduce the societal divide of systems versus life worlds without offering institutional platforms to confront societal macro analyses from political science, economics, sociology with research that focuses on interpersonal domains and personal experiences such as psychology, anthropology or the humanities.

The tensions between person-oriented life world perspectives and the impersonal, formally regulated systemic perspectives that take place inside, for instance, (inter)national political institutions or large corporations are also crucially important for the daily realities of aging persons. I propose that the concept of "life worlds" refers not only to the domain of personal relationships, family life or friendship, but extends into the daily interactions, efforts, creativity of those people who work in systemic worlds where decisions are taken with major implications for the daily realities of aging people all over the world. As long as bureaucratic systems are inevitable in contemporary society there will be more or less permanent tensions between the life worlds and the systemic worlds that should remain alive in order to assert the aging experiences of people who are more than mere representations of bureaucratic categories. Probably, the creative sensitivity still has to come from the interactive life world, where aging persons not only propagate, but "embody" inspiring and supportive views on aging or struggle with oppressive situations or societal exclusion. However, the relation between the systemic worlds and the life worlds should not be treated as a dichotomy: processes of tension and interchange between life worlds and systems can also be potentially creative processes of change. While many professionals are searching for improvements, alternatives and experiments within the tight parameters of the societal systems that restrict the range of their projects, the intermediate platforms that could support these efforts are lagging behind the usual rhetoric about interdisciplinary work.

Narratives play an important role at this intermediary level as they both express aging experiences and articulate in public debates how major 
International Journal of Ageing and Later Life

issues of aging should be seen and dealt with. Although many macronarratives are constructed professionally as they are intended to serve the interests of systems in legitimizing their policies, this situation implies also that these systems need the support they try to gain through their narratives. The somewhat ironic or even cynical formula of the National Priorities Project "so that people can understand and influence how their tax dollars are spent" also points to the dependence of these systems on the understanding support by their populations. They need their narratives to be accepted and believed. Although the power of systems that regulate important societal domains such as educational opportunities, labor markets, health care, institutional care, insurances or pensions is not merely caused by the persuasive quality of their narratives, yet they need to convince whoever they are addressing and here we can follow them with some critical attention. An inspiring culture of aging needs inspiring but also critically interrogative narratives.

\section{Corresponding Author}

Jan Baars, Interpretative Gerontology, University of Humanistic Studies, Utrecht, The Netherlands. Email: info@janbaars.nl

\section{References}

Achenbaum, W. A. (2007). Older Americans, Vital Communities: A Bold Vision for Societal Aging. Baltimore, MD: Johns Hopkins University Press.

Alwin, D. F. \& McCammon, R. J. (2004). Generations, cohorts, and social change. In J. T. Mortimer \& M. J. Shanahan (eds.), Handbook of the Life Course (pp. 23-50). New York: Springer.

Arendt, H. (1958). The Human Condition. Chicago, IL: University of Chicago Press.

Augustine, A. (1961). Confessions. London: Penguin.

Baars, J. (1997). Concepts of Time and Narrative Temporality in the Study of Aging. Journal of Aging Studies 11: 283-296.

Baars, J. (2007). A triple temporality of aging: Chronological measurement, personal experience and narrative articulation. In J. Baars \& H. Visser 
(eds.), Aging and Time: Multidisciplinary Perspectives (pp. 15-42). Amityville, NY: Baywood.

Baars, J. (2010a). Philosophy of aging, time, and finitude. In T. R. Cole, R. Ray \& R. Kastenbaum (eds.), A Guide to Humanistic Studies in Aging (pp. 105-120). Baltimore: Johns Hopkins University Press.

Baars, J. (2010b). Time and aging: Enduring and emerging issues. In D. Dannefer \& C. Phillipson (eds.), International Handbook of Social Gerontology (pp. 367-376). New York: Sage.

Baars, J. (2012). Aging and the Art of Living. Baltimore, MD: Johns Hopkins University Press.

Baars, J. Cultural aspects of time. In J. Twigg \& W. Martin (eds.), Routledge Handbook of Cultural Gerontology. London: Routledge (forthcoming).

Brown, D. E. (1991). Human Universals. New York: McGraw-Hill.

Burrow, J. A. (1986). The Ages of Man. A Study in Medieval Writing and Thought. Oxford, UK: Oxford University Press.

Derrida, J. (1976). Of Grammatology. Baltimore, MD: Johns Hopkins University Press.

Estes, C. (2006). Critical Feminist Perspectives, Aging, and Social Policy. In J. Baars, D. Dannefer, C. Phillipson \& A. Walker (eds.), Aging, Globalization and Inequality (pp. 81-101). Amityville, NY: Baywood.

Fontana, A. \& Frey, J. H. (2000). The interview: from structured questions to negotiated texts. In N. K. Denzin \& Y. S. Lincoln (eds.), Handbook of Qualitative Research (2nd ed., pp. 645-672). Thousand Oaks, CA: Sage.

Gadamer, H. G. (1993). Ueber leere und erfüllte Zeit [About empty and fulfilled time]. In W. Ch. Zimmerli \& M. Sandbothe (Her), Klassiker der modernen Zeitphilosophie (pp. 281-298). Darmstadt, Germany: WBG.

Glenn, N. D. (2004). Distinguishing age, period, and cohort effects. In J. T. Mortimer \& M. J. Shanahan (eds.), Handbook of the Life Course (pp. 465-476). New York: Springer.

Gullette, M. M. (2004). Aged by Culture. Chicago, IL: University of Chicago Press.

Habermas, J. (1987). The Theory of Communicative Action. Volume 2. Lifeworld and System: The Critique of Functionalist Reason. Oxford: Polity Press.

Hagestad, G.O. \& Dannefer, D. (2001). Concepts and theories of aging. Beyond microfication in social science approaches. In R. H. Binstock \& 
International Journal of Ageing and Later Life

L. K. George (eds.), Handbook of Aging and the Social Sciences (5th ed., pp. 3-21). San Diego: Academic Press.

Hall, S. S. (2003). Merchants of Immortality: Chasing the Dream of Human Life Extension. Boston, MA: Houghton Mifflin.

Handel, G. (2000). Making a Life in Yorkville: Experience and Meaning in the Life-Course. Westport, CT: Greenwood Press.

Heidegger, M. (1996). Being and Time. Albany, NY: SUNY Press.

Holstein, J. A. \& Gubrium, J. F. (1997). The Self We Live By: Narrative Identity in a Postmodern World. New York: Oxford University Press.

Husserl, E. (1970). The Crisis of European Sciences and Transcendental Philosophy: An Introduction to Phenomenological Philosophy. Evanston, IL: Northwestern University Press.

Kenyon, G. M., Clark, P. G. \& De Vries, B. (2001). Narrative Gerontology: Theory, Research, and Practice. New York: Springer.

King, N. \& Calasanti, T. (2006). Empowering the old: Critical gerontology and anti-aging in a global context. In J. Baars, D. Dannefer, C. Phillipson \& A. Walker (eds.), Aging, Globalization and Inequality: The New Critical Gerontology (pp. 199-227). Amityville, NY: Baywood.

Lessing, D. (2003). Interview. Times Online, November 23.

Lessing, D. (2009). Alfred and Emily. New York: Harper Perennial.

Lyotard, J. F. (1991). The Inhuman: Reflections on Time. Cambridge, UK: Polity Press.

MacIntyre, A. (1981). After Virtue: A Study in Moral Theory. Notre Dame, France: University of Notre Dame Press.

Ochs, E. \& Capps, L. (2001). Living Narrative: Creating Lives in Everyday Storytelling. Cambridge, MA: Harvard University Press.

Penrose, R. (2010). The Cycles of Time: An Extraordinary New View of the Universe. London: Knopf.

Plato, Phaedrus (1999). Plato in twelve Volumes, Cambridge, MA: Harvard University Press.

Ricoeur, P. (1984). Time and Narrative. Volume 1. Chicago, IL: University of Chicago Press.

Ricoeur, P. (1985). Time and Narrative. Volume 2. Chicago, IL: University of Chicago Press.

Ricoeur, P. (1988). Time and Narrative. Volume 3. Chicago, IL: University of Chicago Press. 
Ricoeur, P. (1991). Narrative identity. In D. Wood (ed.), On Paul Ricoeur (pp. 188-200). London: Routledge.

Sandel, M. J. (1996). Democracy's Discontent: America in Search of a Public Philosophy. Cambridge, MA: Harvard University Press.

Sartre, J. P. (1969). Nausea. New York: New Directions Publishing.

Schaie, K. W. (2007). The concept of event time in the study of adult development. In J. Baars \& H. Visser (eds.), Aging and Time: Multidisciplinary Perspectives (pp. 121-136). Amityville, NY: Baywood.

Sears, E. (1986). The Ages of Man. Medieval Interpretations of the Life Cycle. Princeton, NJ: Princeton University Press.

Stock, G. (2003). Redesigning Humans: Choosing our Genes, Changing our Future. Boston, MA: Houghton Mifflin.

Taylor, C. (1989). Sources of the Self. The Making of the Modern Identity. Cambridge, UK: Cambridge University Press.

Tedlock, B. (2000). Ethnography and ethnographical representation. In N. K. Denzin \& Y. S. Lincoln (eds.), Handbook of Qualitative Research (2nd ed., pp. 445-486). Thousand Oaks, CA: Sage.

Thomae, D. (1998). Erzähle Dich Selbst. Lebensgeschichte als philosophisches Problem [Tell me about yourself. Life history as a philosophical problem]. München, Germany: Beck.

Yates, F. F. (2006). Further conjectures on the nature of time in living systems: Causes of senescence. In J. Baars \& H. Visser (eds.), Aging and Time: Multidisciplinary Perspectives (pp. 177-186). Amityville, NY: Baywood.

Wittgenstein, L. (1953). Philosophische Untersuchungen/Philosophical Investigations. Oxford, UK: Blackwell. 